\title{
Detection of Fluorescent Body in Spermatozoa of Bull, Boar, Dog, Rabbit, Rat and Mouse
}

\author{
Shyoso Ogawa, Hirohito Yamakawa, Junko Yamanor, Shiichi Nishida*, \\ Tutomu Takeshima**, Tetsurou Matumoto***, Yoshinori Tauchi**, \\ Hiroshi Nagashima****, Yasuhiko Kanou \\ Dept. of Animal Reproduction, Meiji University, 1-1-1 Higashimita Tama Kawasaki 214, \\ **Imamichi Institute for Animal Reproduction, ***Tokyo Metropolitan Livestock \\ Experiment, ****Research Center Nishin Flour Milling Co. Ltd.
}

(Accepted for publication June 24, 1987)

\begin{abstract}
Summary. An attempt was made to identify the fluorescent body (F-body), with Quinacrine mustard $(\mathrm{Q}-\mathrm{M})$ staining, in the spermatozoa from 7 mammalian species (human, bull, boar, dog, rabbit, rat and mouse). Washed sperm suspension in PBS was either stained with Q-M solution for $40 \mathrm{~min}$ or $24 \mathrm{hr}$, or treated with Protease and then stained with Q-M for 40 or $100 \mathrm{~min}$. The final concentration of $\mathrm{Q}-\mathrm{M}$ in sperm suspension was $0.025 \mathrm{mg} / \mathrm{ml}$. The microscopic examination, using a reflected fluorescence microscope (B-exciter filter; $390 \sim 490 \mathrm{~nm}$, Optical suppression filter; $\geqq 510 \mathrm{~nm}$ ), revealed that the same F-body as that in human sperms was present in all of these species. After $24 \mathrm{hr}$ staining, F-body was found in 28.5, 28.4, 36.2, 3.0, 9.7 and $9.3 \%$ of sperms of bull, boar, rabbit, dog, rat and mouse, respectively. Enzyme treated specimens showed higher incidences $43.8,44.0,47.6$ and $41.0 \%$ for bull, boar, rabbit and dog, respectively, and 20.4 and $20.7 \%$ for mouse and rat, and $32.5 \%$ for human) of the F-body than those in the specimens stained $24 \mathrm{hr}$ without enzymatic digestion. These findings led to the conclusion that the F-body is present in common with spermatozoa of many mammalian species including man and gorila.

The successful detection of F-bodies in the sperms from various mammalian species is attributed to; (1) the long-term submersion of specimens in the Q-M solution for staining and (2) the treatment of the membrane by protein digestion which yielded more favorable condition for staining in many animal species. KEY WORDS; F-BODY, SPERMS.
\end{abstract}

Jpn J Anim Reprod 33, 140-145, 1987

\footnotetext{
牛・豚・犬・家鬼・ラットおよびマウス精子における 蛍光小体 (F-body) の検出

尾川 昭三・山川 宏人 ・ 山井 淳子 ・ 西田 司一*・竹島 勉** 松本 徹郎 ${ }^{* * *} \cdot$ 田内 正賢**・長嶋比吕志**** ・加納 康彦

明治大学農学部 214 神奈川県川崎市多摩区東三田 1-1-1 **元東京大学農学部 **動物繁殖研究所.***東京都畜産試験場 . *****日清製粉 (株) 中央研究所
}

Zech（1969）はキナクリンマスタード（Q-M）染色 されたヒトの細胞には，分裂中期の像でY染色体長腕部

* Former Address; Dept. Veterinary Med., The University of Tokyo
の末端に強く螢光を発する小体のあるのを認めた。 Pearson et al.,(1970) はヒトの男性の細胞の Q-M 染 色では interphase の核に螢光小体 (Fluorescent Body; F-body）が高頻度に観察されたと報告した。Barlow and 
Vosa（1970）はY染色体に認められる F-body は精子 にも出現することを報告した。彼らは，この F-body を 有する精子はY染色体精子であり, これを欠く精子をX 染色体精子であると推論した。現在では, この推論は妥 当と考えられていて, ヒトのY染色体精子の識別には F-body が指標として用いられるようになった。Pearson et al. (1971) は Q-M 染色による F-body の出現は 全哺乳動物細胞のY染色体に共通しているかどうかを 24 種の動物のリンパ細胞についてしらべた。その結果, F-body はヒトとゴリラの細胞にのみ認められた。果し て, この様なY染色体を示す F-body はヒトや一部の霊 長類に特有なものであろうか。

一方, Bhattacharya (1976) はウシおよびウマの精子 にタンパク分解醉素で消化処置してから Q-M 染色を施 した結果, ヒトの精子頭部にみられると全く同様な螢光 小体が両者の動物の約 $1 / 2$ の細胞に認められたと報じ た。彼はこの精子をY染色体精子と結論している。以来 10年以上を経過したが，その間，この Bhattacharya の知 見を支持する研究報告は全く見当らない。依然として, F-body はヒトのY染色体精子に（一部の霊長類を含む） 特有なものであるとの考え方が支配的である。我及は, この F-body はヒトのみならず,家畜, 小実験動物のY染 色体精子に共通すること示す知見を得たので報告する。

\section{材料と方法}

用いた精子はヒト，ウシ(ホルスタイン種)，ブタ（デ ュロック種), イヌ (ビーグル犬種), 家鬼 (ニュージー ランドホワイト種), ラット (ウイスター系), マウス (ICK 系) のものである。ヒト, ウシ, ブタ, イヌ拉 び家鬼の射精精液（家鬼およびヒト精液は液化後）を80 $\sim 100 \times \mathrm{g}, 5$ 分間遠心分離して沈渣部を棄て, 残る上層 部分を採取した。これにダルベッコの PBS (pH 6.8) を2 倍量加えて遠心分離 $(200 \sim 250 \times \mathrm{g}, 10 \sim 15$ 分間 $)$ した。沈澱精子部分について 3 倍量の PBS を加えて遠 心分離（200～ $250 \times \mathrm{g} ， 10 \sim 15$ 分間）する精子洗浄操作 を 3 回反復した。得られた 洗浄精子部分を 5 分間静置 し，上方に浮遊してくる精子部分を染色に供した。一方， ラットおよびマウスでは頸椎脱臼法により殺し, 精巣上 体尾部を摘出し，この分離尾部を $1 / 2$ 皮下注射針にて穿 刺した後, 尾部の圧迫により穿刺孔より圧出された精子 塊を得た。これを $0.4 \mathrm{ml}$ の HER 液 (Ogawa et al. 1971）に移して $5 \sim 10$ 分間 $37^{\circ} \mathrm{C}$ で保持した後, 精子が 浮遊して HER 液が白濁したものを微細ピペットで採取 した。これに PBS (pH 6.8) を 2 倍量ずつ加えて 3 回
遠心分離 $(200 \times \mathrm{g} ， 10$ およ゙15分間，そして $200 \times \mathrm{g}$, 15分間) で洗浄し，最終回遠心分離の沈澱部の真上に浮 遊走して来た精子部分を採取して染色に供した。これら の分画に含まれる精子の数は必ずしも多くないが，夾雑 物が少なく, 以後の $\mathrm{Q}-\mathrm{M}$ 染色に適していた。

これらの洗浄精子浮遊液には Fig. 1 に示すような, a ）およびb）の 2 種の Q-M 染色が施された。用いた $\mathrm{Q}-\mathrm{M}$ 染色液は $\mathrm{Q}-\mathrm{M} 0.05 \mathrm{mg} / \mathrm{ml}$ 濃度の PBS である。 な扔，予備実験であるが，この濃度より低くても高くて も F-body の検出には不適当であった。

a）上記の洗浄された精子の浮遊液は各 $0.1 \mathrm{ml}$ を小 試験管（径 $10 \mathrm{~mm}$, 長さ $50 \mathrm{~mm}$ ）に移し, これに Q$\mathrm{M}$ 液 $0.1 \mathrm{ml}$ を加えて室温下で 40 分間あるいは一昼夜 保持した。

b) 精子浮遊液 $0.1 \mathrm{ml}$ に対し等量のデイズパーゼ (2000 P.U./ml, Bacillus polymixa の培養液より抽出, 製品化されたプロテアーゼ合同酒精, 東京) 液を混じて $37^{\circ} \mathrm{C}$ で10 15分間保持してタンパク消化処置した。次 いで $\mathrm{Q}-\mathrm{M}$ 液を $0.2 \mathrm{ml}$ 加えた。これを室温で振蕰しな がら40分あるいは 100 分間保持した。

a ）打よび b ) の両者共に Q-M 液を添加した後, 直ち 亿試験管外側をアルミ箔で被覆して, 鏡検するまでの間, 外部の光線から遮断された。

試料の検查には落射型螢光顕微鏡 (BHS-RFK：オリ ンパス光学) が用いられた。B励起フイルターは 390〜 $490 \mathrm{~nm}$, 補助吸収フイルターは $515 \mathrm{~nm}$ 以上の波長のも のが, 光源は超高圧水銀灯 (USH-200 Mb) が, そして 対物レンズは S plan $40 \times$ が用いられた。

染色処置された精子浮遊液はスライドグラス (Precleaned $76 \times 26 \mathrm{~mm}$ Matsunami Ltd.) 中央部に 1 滴 (約 $0.002 \mathrm{ml}$ ) を落として，その上方からカバーグラスで被 い，精子が移動しないようになるまでカバーグラスを圧 してからカバーグラスの周囲を市販のネイルエナメルで 封じた。この精子を螢光顕微鏡で観察し, 各試料につい て 200 個の精子を数え, その頭部に F-body を有するも のの率 $(\%)$ が算出された。

\section{結果と考察}

本研究に用いた $Q-M$ 染色によりヒト精子頭部に認め られる F-body と全く同じ螢光小体が用いた 7 種の哺乳 動物精子に認められた (Fig. 1)。ただし醉素処理をしな いで $\mathrm{Q}-\mathrm{M} 0.025 \mathrm{mg} / \mathrm{ml}$ 液の染色40分の処理のもので は, この 7 種の動物精子には F-body は認められなかっ た。一方, 酵素処理をしなくても一昼夜そのまま染色液 

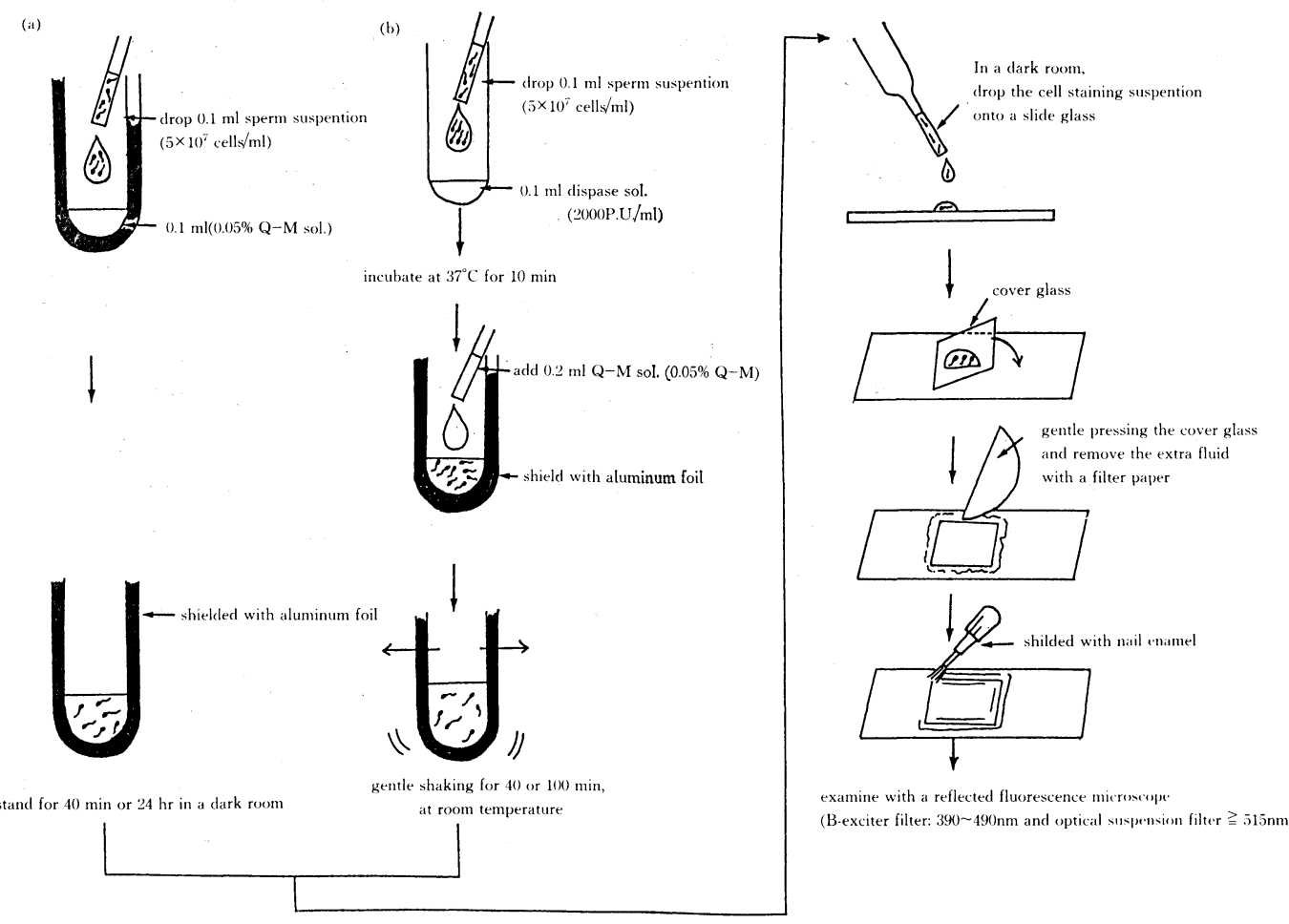

examine with a reflected fluorescence microscope

(B-exciter filter: $390 \sim 490 \mathrm{~nm}$ and optical susprension filter $\geqq 515 \mathrm{~nm}$ )

Fig. 1. Processing of quinacrine mustard staining for F-body detection in mammalian spermatozoa.

中に保持しておいた精子では，F-body の存在が用いた 全動物種に打いて認められた。その出現率は Table 1 に 示す外く, ウシ，ブタおよび家鬼の精子では各28，30お よび $38 \%$ に達した。

しかし，イヌ，ラット抢よびマウス精子では極めて低 く,2〜9\% であった。一方，デイスパーゼで消化処理 後の精子では, $Q-M$ 液40分間の染色により, 前述の醅 素無処理で一昼液染色されたものよりも高い F-body 検 出率が得られた。平均出現率はウシ $43 \%$, ブタ $46 \%$, 家鬼 $48 \%$ ，そしてヒト $27 \%$ であった。すなわちこの 醳素処理は F-body の検出のための前処理として有効で あった。然し, 酵素処理後, 100 分の染色を施したもの では，40分の染色に比し F-body の検出率には，著しい 增加は認められなかった。

Rohde et al. (1972) はヒト精子を $3 \%$ トリプシン液 で30分間消化処置すると Q-M 染色による F-body 出現 率が消化処置しないものに比して約 2 倍に增加したこと 報告した。また Bhattacharya (1976) はウシ, ウマの 精子をパパイヤのプロテアーゼで消化処置してから Q-
M 染色すると F-body が認められると報告した。彼は この消化処置が $\mathrm{Q}-\mathrm{M}$ の精子頭部内への透過に都合のよ い状態をもたらすと考えた。我々がこの研究で得た結 果もこれら Rohde et al. (1972) 打よび Bhattacharya (1976)の両報告と一致している。動物種によって Q-M の精子頭部内への透過性に違いがある可能性が考えられ る。24時間の染色の結果は, 家鬼, ブタおよびウシの精 子では他の動物種のものに比し Q-M の透過性あるいは Q-M と染色体の螢光小体部位との結合性がより良好で ある可能性を示唆している。さらに蛋白分解酵素による 消化処理効果は，Q-M の透過に都合の良い状態を作る ばかりでなく, 蛋白消化によって精子表層に附着してい る粒子など(遠心分離によって除去されなかったもの)が 除去され，頭部蛋白消化によって膜層が薄くなることか ら更に F-body 像が精子表層を透して検出され易くして いることも推定される。周知の如くウシ，ブタ，イヌお よび家鬼精子頭部の形状はオタマジャクシ状で厚さが極 めて薄い。それに比してマウス抢よびラット精子頭部に は特殊な厚膜構造がみられる。この構造が F-body の明 

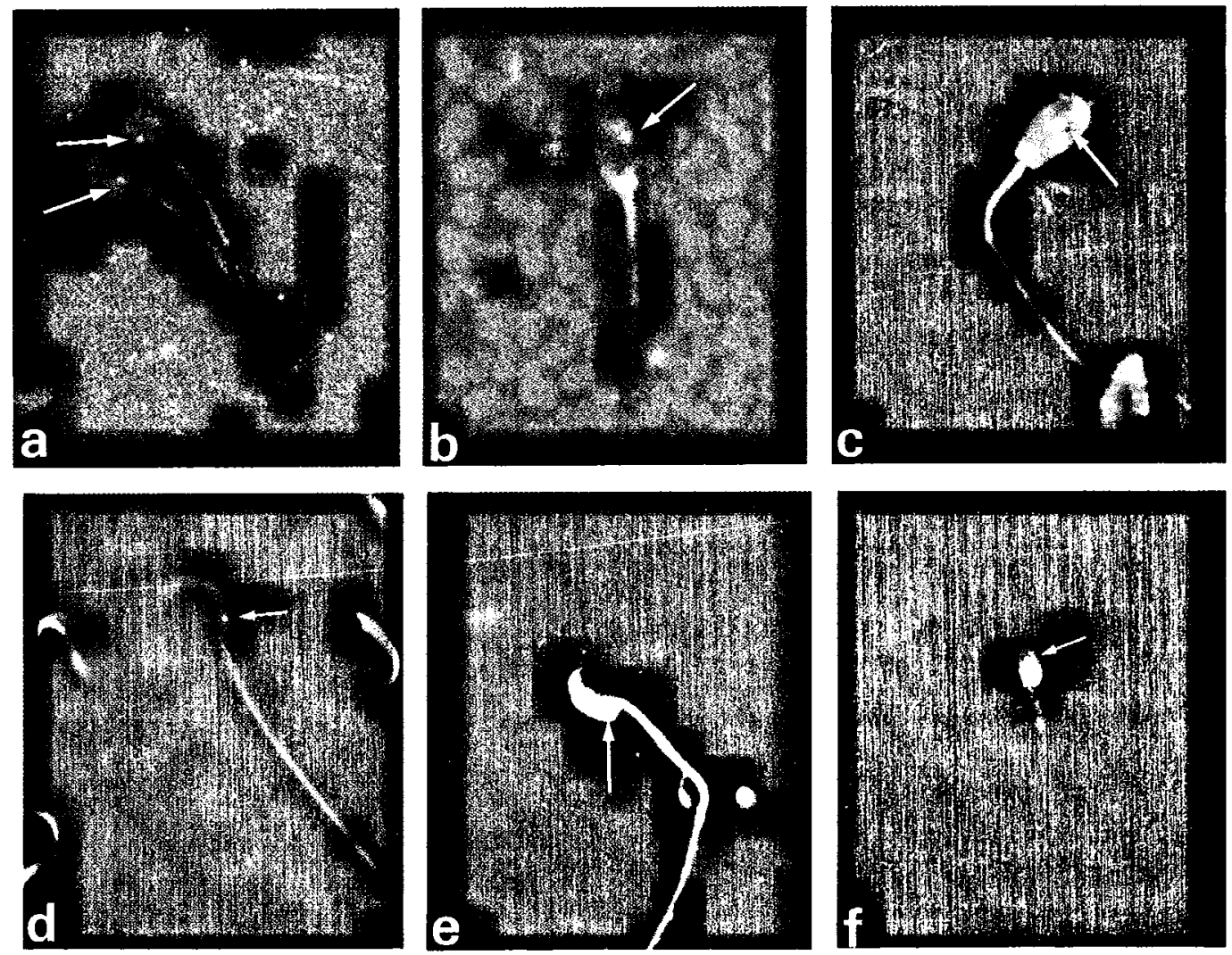

Fig. 2. Micrographs of spermatozoa showing fluorescent-body (arrowed), a: Bull, b: Boar, c: Rabbit (ca. $\times 1500$ ) d: Rat, e: Mouse, f: Human (ca. $\times 1200$ )

膫な検出に障壁となっている可能性がある。前述したよ うに，一昼夜の染色に扔いても消化処置による管光染色 に执いてもこれらの動物に扔ける F-body 検出率は非常 に低いものであったが、これは上記のような頭部形態に よるものかも知れない。なお，この他にY染色体の螢光 小体出現部位に括ける $\mathrm{Q}-\mathrm{M}$ との結合性について種によ る違いがある可能性を考虑する必要があうう。

何故これまで F-body の存在が種々の陠乳動物精子に ついて検出されていなかったのであろうか。ヒトの細胞 や精子で行われたと全く同じ $Q-\mathrm{M}, Q-\mathrm{HCl}$ 䖝光染色 法をそのまま他の動物の精子の染色に適用していたので はないだろらか。例えば染色液の濃度, 染色時間, 更に 染色物質の細胞内への透過性を助ける工夫などに考虑が 払われて来たのかが問題であるう。

本研究では種及の哺乳動物で精子の F-body が検出さ れたが,これは，(1)染色液に封入されたまま試料が鏡検
に供されたことと，(2) Q-M 液の中でも長時間染色処置 されたことなならびに(3)動物種により精子頭部のタンパ ク消化処理が染色に好条件をむたらしたこと，などの点 が F-body 梌出可能となった原因と推定される。

これらの結果は Bhattacharya (1976) がウシ, ウマ精 子に F-body を発見したといら唯一の報告に確証を与え るものである。そして精子 F-body はヒトや一部の霊長 類細胞のY染色体に特有のものであるとの考え方に反証 を与えるものである。我々は，Y染色体精子の F-body は多くの哺乳動物に共通して存在寸るものと推論寸る。

精液中の全Y精子のF-body が检出された場合の率は 50\% になるはずである。Barlow and Vosa (1970) に よればヒトに抢ける F-body の出現率が常に 50\% 以下 であるのは F-body の短㭙間の褪色によると説明した。 一友, Shirai and Matsuda (1972) は正常のヒトの Fbody を有する精子の検出率が F-body 有さない精子 
Table 1. Incidence of F-body detected in the spermatozoa of various mammalian species

\begin{tabular}{|c|c|c|c|c|c|}
\hline \multirow{4}{*}{ species } & \multirow{4}{*}{ No. of Animals } & \multicolumn{4}{|c|}{ Rate of appearance of F-body $(\%$, mean \pm SE) } \\
\hline & & \multicolumn{2}{|c|}{$\begin{array}{l}\text { Staining without } \\
\text { enzymatic } \\
\text { digestion }\end{array}$} & \multicolumn{2}{|c|}{$\begin{array}{c}\text { Staining after } \\
\text { enzymatic (dispase) } \\
\text { digestion (10 min) }\end{array}$} \\
\hline & & \multicolumn{4}{|c|}{ Quinacrine Mustard Staining } \\
\hline & & $40 \mathrm{~min}$ & $24 \mathrm{~h}$ & $40 \mathrm{~min}$ & $100 \mathrm{~min}$ \\
\hline & & $\%$ & $\%$ & $\%$ & $\%$ \\
\hline Mouse & 8 & 0 & $9.25 \pm 1.01$ & $20.25 \pm 1.41$ & $20.38 \pm 1.16$ \\
\hline Rat & 3 & 0 & $9.67 \pm 2.19$ & $18.33 \pm 1.33$ & $20.67 \pm 1.76$ \\
\hline Rabbit & 5 & 0 & $36.20 \pm 1.83$ & $47.60 \pm 4.34$ & $45.00 \pm 3.69$ \\
\hline Dog & 3 & 0 & $3.03 \pm 1.53$ & $38.00 \pm 4.51$ & $41.01 \pm 4.93$ \\
\hline Boar & 5 & 0 & $28.40 \pm 1.94$ & $44.00 \pm 1.73$ & $43.60 \pm 1.29$ \\
\hline Bull & 4 & 0 & $28.50 \pm 2.87$ & $42.25 \pm 2.87$ & $43.74 \pm 2.29$ \\
\hline Human & 4 & 0 & $3.25 \pm 1.18$ & $27.50 \pm 1.71$ & $32.54 \pm 1.94$ \\
\hline
\end{tabular}

に比し常に低いことの原因として，正常人においても常 に数％の形成不全, すなわち Q-Mによって染色され ない異常な核を有する精子が存在するためと推論した。 この実験で F-body 出現率の高い值の得られた動物, 家 鬼, ウシ，ブタ精子でも F-body の平均出現率は $50 \%$ より数\%低い值であった (Table 1)。精液の洗浄回数 の增加に伴い微細な夾雑物や精子表面に附着している夾 雑物が取り払われた標本では，F-body の出現率が増 加する事実 (未発表資料) から, 上記 4 種の動物精子で F-body 出現率が $50 \%$ に満たない理由の 1 つとして技 術的な失宜によることが推察される。

従来より家畜に扔いて，X染色体精子と $\mathrm{Y}$ 染色体精子 を分離しようとする試みが枚挙にいとまのない程の数多 くの人々によってなされできた。しかし，分離処理され て得られた精子が $\mathrm{X}$ 染色体精子か $\mathrm{Y}$ 染色体精子かを識別 し得る簡単で信頼し得る方法は確立されていない。本実 験で得られた知見は家畜や小実験動物のY染色体精子の 同定をヒトY染色体精子に打けると同様に行い得る可能 性を示唆している。この F-body 検出法を更に信頼性の 高いものにするべく, 研究を続ける必要がある。そのよ うにして得られたこの F-body の検出方法は家音や小実 験動物に打けるX染色体精子とY染色体精子の分離によ る選択的性の動物生産に関する研究に利用されるのみな らず，その実用化にはずみをつけ，その進歩に貢献する ものと考えられる。

\section{References}

Barlow P, Vosa CG (1970) The $Y$ chromosome in human spermatozoa. Nature 226: 961-692.

Bhattacharya BC (1976) Pre-determination of sex in animal reproduction. Proc 8th Intn Cong Anim Reprod Art Insem 4: 876-878.

Dulbecco R, Vogt M (1954) Plaque formation and isolation of pure lines with poliomyelitis viruses. J Exp Med 99: 167-182.

Ogawa S, Satoh K, Hashimoto $\mathrm{H}$ (1971) In vitro culture of rabbit ova from the single cell to the blastocyst stage. Nature 233: 422-424.

Person PL, Bobrow M (1970) Fluorescent staining of the $\mathrm{Y}$ chromosome in meiotic stages of the human male. J Reprod Fert 22: 177-179.

Person PL, Bobrow M, Vosa CG, Barlow PW (1971) Quinacrine Fluorescence in mammalian chromosomes. Nature 231: 326-329.

Rohde W, Porstmann T, Zillmann R, Dörner G (1972) Zum fluoreszenzmikroskopischen Nachweis des $\mathrm{Y}$ Chromosomes in unbehandelten und trypsinbehandelten menschlichen Spermien. Acta Biol Med Germ 28: 189-192.

Shirai M, Matsuda S (1972) Fluorescent bodies in the spermatozoa of patients with sterility. Jap J Fert \& Ster 18: 239-242, 243-245 (in Japanese).

Zech L (1969) Investigation of metaphase chromosomes with DNA-binding fluorochromes. Exp Cell Res 58: 463 (Abst). 


\section{要 約}

我々はキナクリンマスタード $(\mathrm{Q}-\mathrm{M})$ を用いて 7 種類の哺乳動物（ヒト，ウシ，ブタ，イヌ，家鬼， ラット，マウス）から得た精子に螢光染色を施し，F-body の検出を試みた。これらの動物から得た 精子をよく洗浄し，(a)その精子浮遊液 $0.1 \mathrm{ml}$ を等量の $\mathrm{Q}-\mathrm{M}$ 液と混合し，40分間あるいは一昼夜室 温に放置した。扎よび，(b)デイスパーゼ液（2000 P.U./ml） $0.1 \mathrm{ml}$ 在加え， $37^{\circ} \mathrm{C}$ で10〜15分間保持

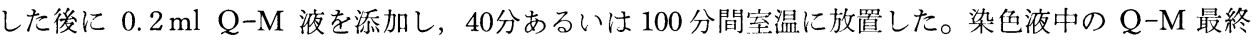
濃度は $0.025 \mathrm{mg} / \mathrm{ml}$ であった。精子浮遊染色液をスライドグラスに載せ，カバーグラスで覆って螢 光顕微鏡下で観察した（B-励起フイルター；390〜 490 nm，補助吸収フイルター; $\geqq 515 \mathrm{~nm}$ )。一昼 夜の染色後の観察で，ヒト精子に出現したものと同じ F-body が 6 種類の動物の精子に観察され，ウ シ，ブタ，家鬼ではそれぞれ 28.5\%，28.4\%，36.2\%，イヌ，ラット，マウスではそれぞれ $3.0 \%$, 9.7\%，9.3\% であった。一方，酵素処理を施した標本は，酵素処理せずに一昼夜染色した標本よりも F-body の出現率は高く，ウシ，ブ夕，家鬼，イヌではそれぞれ 43.8\%，44.0\%，47.6\%，41.0\%， マウスとラットではそれぞれ $20.4 \% ， 20.7 \%$ ，ヒトでは $32.5 \%$ であった。以上の如く，様々な哺 乳動物種から得た精子に F-body が発見できた理由に，(1)標本の Q-M 染色を長時間行ったこと，(2) 酵素による細胞膜のタンパク質消化が，染色に好条件をもたらしたこと，が挙げられる。 